\title{
Distribution and Acute Stressor-Induced Activation of Corticotrophin-Releasing Hormone Neurones in the Central Nervous System of Xenopus laevis
}

\author{
M. Yao*1, N. J. Westphalt ${ }^{1}$ and R. J. Denver*† \\ *Department of Molecular, Cellular and Developmental Biology and +Neuroscience Program, The University of Michigan, Ann Arbor, MI, USA.
}

Key words: corticotrophin-releasing hormone, stress, Xenopus, amphibian, Fos.

\begin{abstract}
In mammals, corticotrophin-releasing hormone $(\mathrm{CRH})$ and related peptides are known to play essential roles in the regulation of neuroendocrine, autonomic and behavioural responses to physical and emotional stress. In nonmammalian species, $\mathrm{CRH}$-like peptides are hypothesized to play similar neuroendocrine and neurocrine roles. However, there is relatively little detailed information on the distribution of $\mathrm{CRH}$ neurones in the central nervous system (CNS) of nonmammalian vertebrates, and there are currently no comparative data on stress-induced changes in $\mathrm{CRH}$ neuronal physiology. We used a specific, affinitypurified antibody raised against synthetic Xenopus laevis CRH to map the distribution of CRH in the CNS of juvenile South African clawed frogs. We then analysed stress-induced changes in $\mathrm{CRH}$ immunoreactivity ( $\mathrm{CRH}$-ir) throughout the CNS. We found that $\mathrm{CRH}$-positive cell bodies and fibres are widely distributed throughout the brain and rostral spinal cord of juvenile $X$. laevis. Strong $\mathrm{CRH}$-immunoreactovity (ir) was found in cell bodies and fibres in the anterior preoptic area (POA, an area homologous to the mammalian paraventricular nucleus) and the external zone of the median eminence. Specific $\mathrm{CRH}$-ir cell bodies and fibres were also identified in the septum, pallium and striatum in the telencephalon; the amygdala, bed nucleus of the stria terminalis and various hypothalamic and thalamic nuclei in the diencephalon; the tectum, torus semicircularis and tegmental nuclei of the mesencephalon; the cerebellum and locus coeruleus in the rhombencephalon; and the ventral horn of the rostral spinal cord. To determine if exposure to an acute physical stressor alters $\mathrm{CRH}$ neuronal physiology, we exposed juvenile frogs to shaking/handling and conducted morphometric analysis. Plasma corticosterone was significantly elevated by 30 min after exposure to the stressor and continued to increase up to $6 \mathrm{~h}$. Morphometric analysis of $\mathrm{CRH}$-ir after $4 \mathrm{~h}$ of stress showed a significant increase in $\mathrm{CRH}$-ir in parvocellular neurones of the anterior preoptic area, the medial amygdala and the bed nucleus of the stria terminalis, but not in other brain regions. The stressinduced increase in $\mathrm{CRH}$-ir in the POA was associated with increased Fos-like immunoreactivity (Fos-LI), and confocal microscopy showed that CRH-ir colocalized with Fos-LI in a subset of Fos-LI-positive neurones. Our results support the view that the basic pattern of CNS CRH expression arose early in vertebrate evolution and lend further support to earlier studies suggesting that amphibians may be a transitional species for descending CRH-ergic pathways. Furthermore, $\mathrm{CRH}$ neurones in the frog brain exhibit changes in response to a physical stressor that parallel those seen in mammals, and thus are likely to play an active role in mediating neuroendocrine, behavioural and autonomic stress responses.
\end{abstract}

Corticotrophin-releasing hormone $(\mathrm{CRH})$, a 41-amino acid neuropeptide first isolated by Vale and colleagues from the ovine hypothalamus (1), has since been isolated and characterized in representatives of most vertebrate classes (2). Subsequent to its isolation, it was discovered that CRH is a member of a family of related peptides in vertebrates that includes the fish urotensins-I, frog sauvagine and the urocortin/stresscopin peptides (2). Corticotrophin-releasing hormone is generally regarded as the primary hypothalamic neurohormone within the hypothalamic-pituitary-adrenal (HPA) axis responsible for mediating neuroendocrine responses to stress. In addition to its role as a hypophysiotrophin, $\mathrm{CRH}$ also

Correspondence to: Dr Robert J. Denver, Department of Molecular, Cellular and Developmental Biology, 3065C Natural Science Building, The University of Michigan, Ann Arbor, MI 48109-1048, USA (e-mail: rdenver@umich.edu).

${ }^{1}$ These authors contributed equally to the work. 
functions as a neurotransmitter/neuromodulator, mediating autonomic and behavioural responses to stress $(2,3)$. However, these conclusions are based largely on studies in mammals, with little comparative data available in nonmammalian species.

The mature CRH peptide is highly conserved among vertebrates, especially among the tetrapods (2). There are two closely related CRH genes in Xenopus laevis (designated $\mathrm{xCRHa}$ and $\mathrm{xCRHb}$ ) due to the pseudotetraploid nature of its genome (4). The mature peptides encoded by the two genes are identical in their deduced primary amino acid sequences. The amino acid sequences of the CRHs from human and rat are identical, and differ from the frog peptide in only three positions $(5,6)$. Among the few amphibian species in which $\mathrm{CRH}$ has been cloned, the mature peptides of Spea hammondii (GenBank accession \#AY262255) and Phyllomedusa sauvageii (GenBank accession \#AY596828) are identical to $X$. laevis (GenBank accession \#S50096), while the CRH of Rana catesbeiana differs from the other anuran peptides in only the first amino acid residue (GenBank accession \#AB161633).

In mammals, $\mathrm{CRH}$ is widely distributed throughout the CNS, but a circumscribed group of parvocellular neurosecretory neurones localized to the paraventricular nucleus of the hypothalamus (PVN) comprise the major hypophysiotropic neurones of the HPA axis. The PVN neurones are the principal source of CRH delivered to the external zone of the median eminence, where $\mathrm{CRH}$ is released into the hypophyseal portal system and subsequently stimulates the release of adrenocorticotrophic hormone from the anterior pituitary $(7$, 8).

Earlier studies of the distribution of CRH-like immunoreactivity in amphibians depended on the use of antisera raised against mammalian CRHs. CRH-immunoreactivity (ir) has been shown in somata and fibres in the brain and pituitary of several amphibian species: Urodela: Pleurodeles waltii, Ambystoma mexicaum (9) and Triturus cristatus (10); Anura: Rana ridibunda $(9,11)$, Rana catesbeiana $(11)$ and $X$. laevis $(9$, 12). In these studies, the greatest intensity of CRH-like immunoreactivity was found in the preoptic nucleus (homologue of the mammalian PVN) and in the external zone of the median eminence. Close morphological examination of $\mathrm{CRH}$ projections in ranid frogs revealed that the $\mathrm{CRH}$ neurones of the ventral preoptic nucleus project caudally and terminate in the external zone of the median eminence $(11,13,14)$.

Most studies in amphibians have focused on the hypophysiotropic $\mathrm{CRH}$ neurones and little attention has been directed towards other CRH systems in the brain and spinal cord. Using heterologous antisera Bhargava and Rao (15) reported $\mathrm{CRH}$-ir in the mesencephalon (optic tectum and interpeduncular nucleus) of tiger frogs and Olivereau et al. (9) reported CRH-ir in the cerebellum and interpeduncular nucleus of two ranid and two urodele species. In rats, the $\mathrm{CRH}$ neurones of the PVN (particularly the parvocellular neurones) have been shown to be stress-responsive. For example, CRH gene expression (mRNA, heteronuclear RNA or $\mathrm{CRH}-\mathrm{ir}$ ) increased in the PVN following exposure to different stressor paradigms (16-26). However, these neurones respond differently to different kinds of stressors, and decreases in $\mathrm{CRH}$ gene expression (mRNA or $\mathrm{CRH}$-ir) in these cells as well as no change have been reported (18, 2729). Similar studies have yet to be conducted in species other than rats.

In the present study, we used homologous, affinity purified antibodies generated against synthetic $X$. laevis $\mathrm{CRH}(\mathrm{xCRH})$ to map the distribution of $\mathrm{CRH}$-ir somata and fibres throughout the CNS of juvenile $X$. laevis. We then used morphometric analysis to analyse stress-induced changes in CRH neuronal physiology throughout the frog brain. Our results support and extend previous studies of CRH-ir in the frog brain by showing, in addition to forebrain and mesencephalic locations previously reported $(9-12,15,30)$, strong $\mathrm{CRH}$ expression in the cerebellum, rhombencephalon and rostral spinal cord of frogs. We also present evidence for stress-activation of $\mathrm{CRH}$ neurones in the anterior preoptic area (POA), the medial amygdala (MeA), and the bed nucleus of the stria terminalis (BNST) in $X$. laevis. We also show that the immediate early gene product Fos (Fos-like immunoreactivity; Fos-LI) increased in the POA following exposure to the stressor and Fos-LI was colocalized with CRH-ir in a subset of Fos-LI-positive neurones.

\section{Materials and methods}

\section{Animals and tissue preparation}

Juvenile $X$. laevis (weighing 2.5-5.0 g) were derived from an inhouse breeding stock (population originally derived from Xenopus I, Dexter, MI, USA). Animals were fed beef liver and maintained at $22-23^{\circ} \mathrm{C}$ on a $12: 12 \mathrm{~h}$ light/ dark cycle. For immunohistochemical mapping of $\mathrm{CRH}$ neurones and processes, animals were anaesthetized by immersion in $0.01 \%$ benzocaine and given intracerebroventricular injections of colchicine $(7.5 \mathrm{ng} / \mu \mathrm{l}$ in $0.06 \%$ saline and 1\% methyl green, 150-200 nl/injection). Frogs were killed $42 \mathrm{~h}$ after injection and the skulls were fixed overnight in $4 \%$ paraformaldehyde at $4{ }^{\circ} \mathrm{C}$.

The brains were dissected and postfixed for $1 \mathrm{~h}$, followed by immersion in $30 \%$ sucrose/phosphate-buffered saline (PBS) at $4{ }^{\circ} \mathrm{C}$ overnight. Following the protection with sucrose, brains were snap-frozen and stored at $-80^{\circ} \mathrm{C}$ until sectioning. Before sectioning, brains were embedded using $\mathrm{M}-1$ embedding matrix (Shandon Lipshaw, Inc., Pittsburgh, PA, USA). Brains were cryosectioned transversely at $12 \mu \mathrm{m}$ and stored at $-80{ }^{\circ} \mathrm{C}$ until analysis. Eight brains were analysed for $\mathrm{CRH}$-ir distribution in the frog CNS.

\section{Antibody purification}

We identified CRH-positive neurones and processes using a polyclonal rabbit antiserum raised against synthetic $X$. laevis $\mathrm{CRH}$ (xCRH) conjugated to human alpha globulins $(31,32)$. The immunoglobilin $(\mathrm{Ig}) \mathrm{G}$ fraction of the $\mathrm{xCRH}$ antiserum was first affinity purified using an Affi-Gel Protein A purification column and a column containing $x \mathrm{CRH}$ conjugated to Affi-Gel 10 (Bio-Rad Laboratories, CA, USA). The construction of the xCRH-Affi-Gel 10 matrix was modified to adjust for the low isoelectric point of $\mathrm{xCRH}$ ( $\mathrm{pI}=5.05$ ) following the manufacturer's specifications. The affinity column was prepared by coupling $1 \mathrm{mg}$ of synthetic xCRH dissolved in $1 \mathrm{ml}$ coupling buffer $\left(0.1 \mathrm{M}\right.$ MOPS $\left.\mathrm{pH}=7.5,80 \mathrm{mM} \mathrm{CaCl}_{2}\right)$ to $0.5 \mathrm{ml}$ washed Affi-Gel 10 matrix. The reaction included 100000 c.p.m. $\left[{ }^{125} \mathrm{I}\right]-\mathrm{xCRH}$ (prepared by the iodogen method) (31) to allow for determination of coupling efficiency (which was $86 \%$ ).

We recently isolated cDNA clones for $X$. laevis urocortin 1 (UCN1) (GenBank accession \#AY596827) and UCN3 (GenBank accession \#AY596826; G. C. Boorse and R. J. Denver, unpublished data) and have synthesized the peptides based on their deduced amino acid sequences. The deduced amino acid sequence of $X$. laevis $\mathrm{UCN} 1$ (xUCN1) is $72.5 \%$ similar to rodent UCN1. Xenopus laevis $\mathrm{UCN} 3$ (xUCN3) shares $87.5 \%$ sequence similarity with rodent $\mathrm{UCN} 3$. We determined the crossreactivities of our $\mathrm{xCRH}$ antiserum with $\mathrm{xUCN} 1$ and $\mathrm{xUCN} 3$ by radioimmunoassay [for crossreactivity analysis with heterologous $\mathrm{CRH}$-like peptides, see (32)]. The 
xUCN1 showed approximately $3 \%$ crossreaction, while UCN3 did not crossreact with the anti-xCRH serum (G. C. Boorse and R. J. Denver, unpublished data). We used these peptides to preabsorb our anti-xCRH IgG before immunohistochemistry (see below).

\section{Immunohistochemistry}

Immunohistochemistry was used to localize xCRH-ir and Fos-like immunoreactivity (Fos-LI) neurones in the brain and rostral spinal cord. The rabbit polyclonal c-fos antiserum that we used (sc-253; Santa Cruz Biotechnology, Santa Cruz, CA, USA) was raised against an epitope that shares $88 \%$ sequence similarity with Xenopus c-fos (communication with Santa Cruz Biotechnology; the sequence of the epitope is proprietary) and has been used successfully for detection of Fos-LI in X. laevis (33). The specificity of our affinity-purified anti-xCRH IgG was confirmed by preabsorption of the primary antibody with synthetic xCRH, xUCN1 or xUCN3 $(50 \mu \mathrm{g} / \mathrm{ml})$ overnight at $4{ }^{\circ} \mathrm{C}$ before immunohistochemistry.

We used two methods to detect CRH-ir and Fos-LI, immunofluorescence or horseradish peroxidase/diaminobenzidine (HRP/DAB). For immunofluorescent detection, sections were incubated in the primary antiserum $[1: 15$ dilution for the anti-xCRH $\operatorname{IgG}$, and $1: 4000$ dilution for anti-Fos serum in PBS with $2 \%$ normal goat serum (NGS)] for $20 \mathrm{~h}$ at $20^{\circ} \mathrm{C}$ or $4{ }^{\circ} \mathrm{C}$. For HRP/ $\mathrm{DAB}$, tissue sections were first incubated in $0.3 \%$ hydrogen peroxide (in distilled water) for $30 \mathrm{~min}$ to quench endogenous peroxidase activity, followed by 30 min incubation in 2\% NGS in PBS. We used a Vectastain elite ABC kit (rabbit) and Vector VIP kit (both from Vector Laboratories, Inc., Burlingame, CA, USA) for HRP/DAB staining following the manufacturer's protocols. The micrographs shown in the figures are derived from HRP/DAB staining (except for the dual immunofluorescence data), but both methods provided identical results with regard to the distribution of CRH-ir cells. However, the immunofluorescence method allowed for better visualization of neuronal processes, and thus CRH-ir fibres depicted in Figs 2 and 3 are based on analysis by immunofluorescence.

Because antisera to both $\mathrm{xCRH}$ and c-fos were generated in rabbits, we conducted dual immunofluorescence histochemistry according to the methods of Negoescu et al. (34). This method depends on sequential incubation with primary antisera and the use of a fluorescein (FITC)-conjugated Fab fragment as the secondary antibody for the first primary antibody (in our case, the anti$\mathrm{xCRH})$. Briefly, cryosections were incubated in blocking buffer $(10 \%$ normal goat serum in TBS) for $1 \mathrm{~h}$ at room temperature and then incubated overnight at $4{ }^{\circ} \mathrm{C}$ with the affinity purified anti-xCRH $\operatorname{IgG}$ diluted $1: 15$ in blocking buffer. Sections were washed three times with TBS and then incubated overnight at $4{ }^{\circ} \mathrm{C}$ with a fluorescein (FITC)-conjugated Fab fragment of goat anti-rabbit IgG $(\mathrm{H}+\mathrm{L})$ (diluted 1: 100; Jackson ImmunoResearch, PA, USA). After rinsing, the sections were incubated with the anti-Fos serum $(1: 4000)$ for $3 \mathrm{~h}$ at room temperature, followed by extensive washes and then incubation with a Cy3-conjugated polyconal goat anti-rabbit $\operatorname{IgG}(1: 1000$; Jackson ImmunoResearch) for $2 \mathrm{~h}$ at room temperature. After rinsing, the sections were nuclear-counterstained with DAPI (200 ng/ml; Sigma D9542; Sigma, St Louis, MO, USA) for $30 \mathrm{~min}$, then cover-slipped with Prolong Anti-Fade (Molecular Probes, OR, USA). To control for crossreaction of the second secondary antibody with the first primary antibody, we conducted interference control staining for the use of Fab fragment as described by Negoescu et al. (34). Briefly, the dual immunofluorescence procedures were conducted by substitution of nonimmune serum for the second primary antiserum (i.e. rabbit anti-Fos serum). No staining by the second secondary antiserum (i.e. Cy3-conjugated goat anti-rabbit IgG) was observed, demonstrating that the Fab fragment of goat anti-rabbit IgG saturated all the immunoreactive sites of the first primary antibody (i.e. rabbit anti-xCRH $\mathrm{IgG}$ ), and no crossreaction occurred between the second secondary antiserum and the first primary antibody. Single immunofluorescence histochemistry for $\mathrm{xCRH}$ or c-fos was also conducted for comparison.

Routine fluorescence microscopy was conducted using an Olympus U-TBI90 microscope and digital images captured using a Retiga 1300R camera. Sections were also analysed by confocal microscopy (Zeiss laser scanning confocal microscope). Optical sections ( $1 \mu \mathrm{m}$ thickness) were captured through the Z-axis to determine if CRH-ir and Fos-LI were colocalized.

\section{Shaking stressor}

Two days before the start of the experiment, juvenile frogs (weighing 5-8 g) were randomly assigned to treatment groups and placed in tanks surrounded by opaque barriers to block visual stimuli. On the day of the experiment, the 'stressed' group was placed into $32 \mathrm{oz}$ white polypropylene containers, with three frogs in $250 \mathrm{ml}$ well water. The containers were placed on an orbital shaker and shaken continuously at 100 r.p.m. for various times. The shaking intensity was just enough to require constant spatial adjustment by the frogs but not enough to cause physical damage (35). The frogs were killed by submersion in $0.05 \%$ benzocaine. The unstressed (nonhandled) group was killed at the same time. For plasma corticosterone analysis, frogs were killed at $0,30 \mathrm{~min}, 3 \mathrm{~h}$ and $6 \mathrm{~h}$ after the initiation of the shaking stressor $(\mathrm{n}=10 /$ time point). For immunohistochemistry, frogs were euthanized at 0 time and then $4 \mathrm{~h}$ after the initiation of the shaking stressor $(n=6 /$ time point). All frogs were weighed, blood was collected immediately into prechilled capillary tubes, and heads were fixed in cold $4 \%$ paraformaldehyde.

\section{Plasma corticosterone radioimmunoassay (RIA)}

Corticosterone was measured in frog plasma using methods described by Licht et al. (36). Briefly, plasma was extracted using diethyl ether and the RIA was conducted using a corticosterone antiserum obtained from Esoterix Endocrinology (San Diego, CA, USA). All samples were measured in a single assay, and the intra-assay coefficient of variation was $10 \%$. The effect of exposure to the shaking stressor on plasma corticosterone content was analysed using one-way analysis of variance of shaking time versus corticosterone content.

\section{Morphometric analysis of CRH immunoreactivity}

CRH immunoreactivity was quantified on brain sections using MetaMorph software (version 6.2r4; Universal Imaging Corporation, Downingtown, PA, USA). All sections were processed simultaneously under identical conditions. Three to five sections containing each brain region of interest were analysed for each animal. All sections were carefully matched for anatomical level, and digital images were captured at $\times 100$ or $\times 200$ magnification for densitometric analysis. A random procedure was carried out throughout the image analysis. The brain regions were analysed using a hand-made frame covering the complete area of interest, and the total area of the positive staining particles above a standard density threshold in the selected area was counted automatically. The mean density for each animal was calculated as the total positive staining area on the multiple sections divided by the total selected area. The effects of the shaking stressor on CRH-ir mean density in the brain regions investigated were analysed by Student's unpaired t-test $(\mathrm{P}<0.05)$ using the SPSS statistical package v11.5 for Windows (SPSS Inc., Chicago, IL, USA).

\section{Results}

\section{Distribution of CRH immunoreactivity in juvenile X. laevis brain and spinal cord}

We found CRH-ir cell bodies and fibres to be widely distributed throughout the CNS of juvenile $X$. laevis. Alternating sections exhibited robust staining in the same neuroanatomical regions. Furthermore, preabsorption of the affinitypurified antibodies with synthetic xCRH completely abolished all staining, while preabsorption with synthetic $\mathrm{xUCN} 1$ or xUCN3 did not alter staining, thus demonstrating the specificity of the antibodies (Fig. 1). Well-organized groups of cells and fibres were found in regions of the telencephalon, diencephalon, mesencephalon, rhombencephalon and rostral spinal cord. Contrary to earlier reports that used heterologous antisera $(13,37)$, we did not observe CRH-ir in the pituitary gland. A schematic representation of the distribution of CRH positive cell bodies and fibres throughout the $X$. laevis brain and rostral spinal cord is shown in Figs 2 and 3.

\section{Telencephalon}

The most rostral sites of CRH-ir were localized to small somata in the mitral layer of the olfactory bulb, the medial 

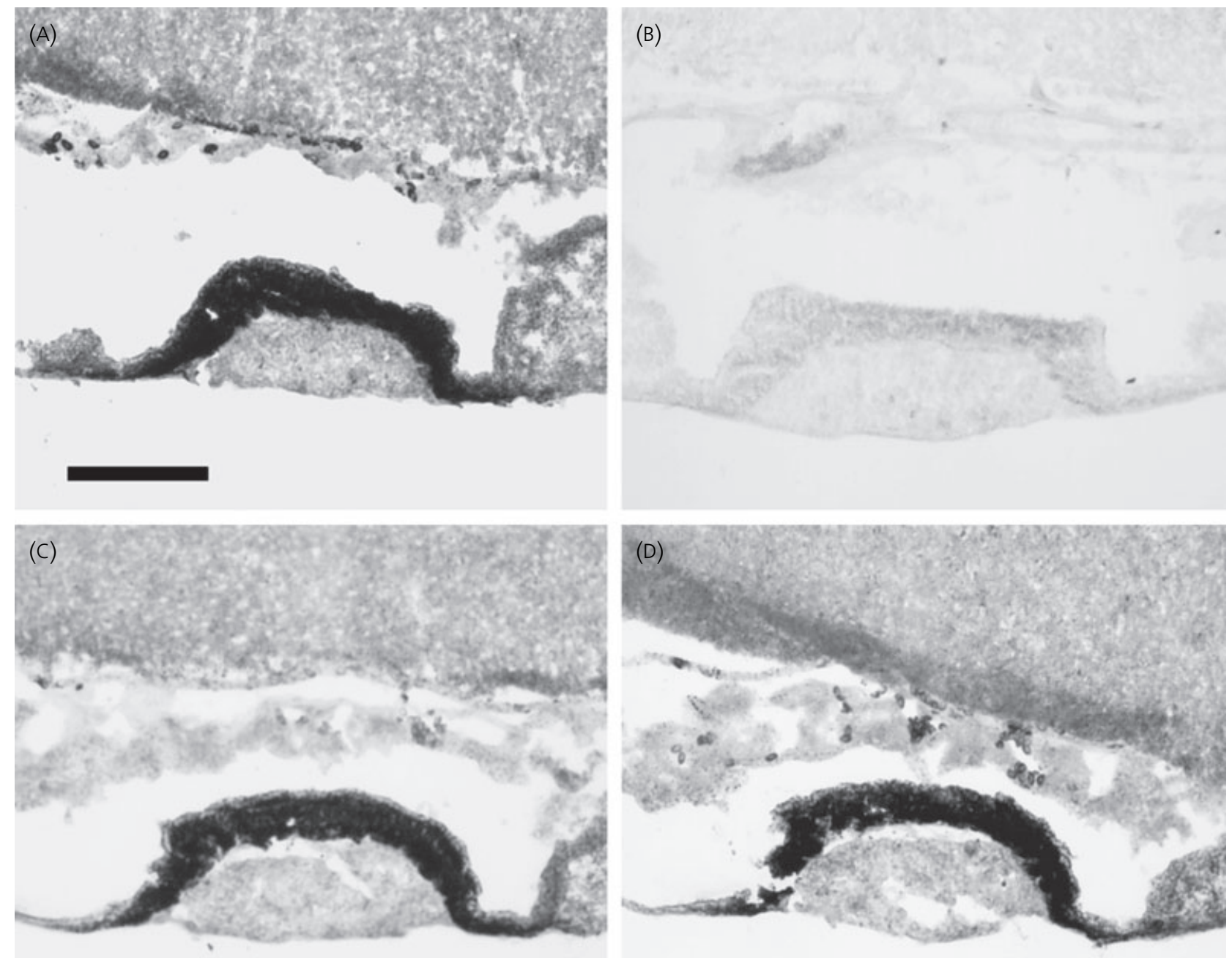

FIG. 1. Photomicrographs of transverse sections through the brain of a juvenile Xenopus laevis at the level of the median eminence showing the specificity of the affinity-purified anti-xCRH immunoglobulin (Ig)G. Dorsal is up in the photomicrographs in this and all other figures. Adjacent transverse sections were incubated with affinity-purified anti-xCRH IgG (A) or with anti-xCRH IgG that had been preabsorbed with $50 \mu \mathrm{g} / \mathrm{ml}$ of synthetic xCRH (B), xUCN1 (C) or xUCN3 (D). Scale bar $=200 \mu \mathrm{m}$.

septum, medial, dorsal and lateral pallium, and striatum. Large somata with CRH-ir axons were found in the nucleus accumbens and less frequently in the lateral pallium (Fig. 2AC; see also Fig. 4A-D).

\section{Diencephalon}

The largest group of CRH-ir cells was found in both the magnocellular and parvocellular divisions of the POA (Fig. 2D,E; see also Fig. 4F). Immunoreactive somata were predominantly found in the subependymal zones with axons projecting medially, sending projections towards the third ventricle, and also laterally. Sparse but large immunoreactive somata were seen in the ependymal zones with axons projecting medially to the ventricle. In caudal regions of the POA, immunoreactive somata were also found in a more dorsal position with axons projecting ventrolaterally.

Scattered, smaller $\mathrm{CRH}$-ir cells and fibres were localized to the amygdala and the bed nucleus of the stria terminalis (Fig. 2D; see also Fig. 4E,G). Well-organized groups of smaller cells were also observed in various hypothalamic and thalamic nuclei (Fig. 2D-F, see also Fig. $4 \mathrm{H}, \mathrm{I})$. In the thalamus, CRH-ir was observed in wellorganized bands of cells consistent with the neuroanatomical organization and localization of the habenular, anterior thalamic, ventromedial thalamic and ventrolateral thalamic nuclei. The ventral thalamus and posterior tubercle contained larger somata, localized to ventricular regions with axons projecting ventrolaterally and dorsolaterally, respectively. Strong immunoreactive fibre staining was present in the external capsule of the median eminence (Fig. $3 \mathrm{H}$; see also Figs 1 and 5B). There was an absence of $\mathrm{CRH}$-ir cells in all pituitary lobes.

\section{Mesencephalon}

Relatively weak but specific staining of smaller cells was observed in the oculomotor nuclei, tectal regions, the torus 


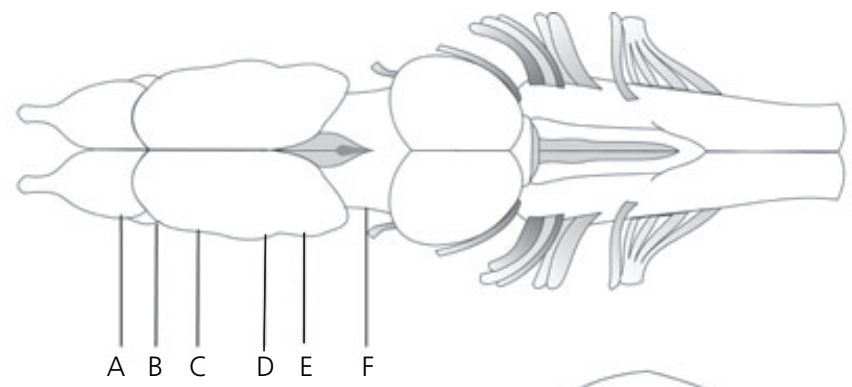

(A)

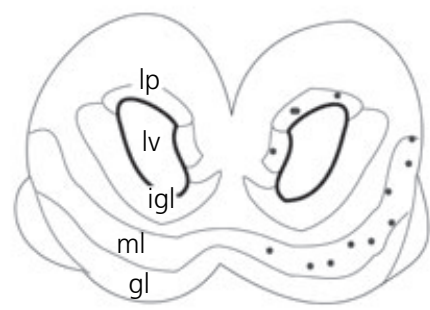

(B)
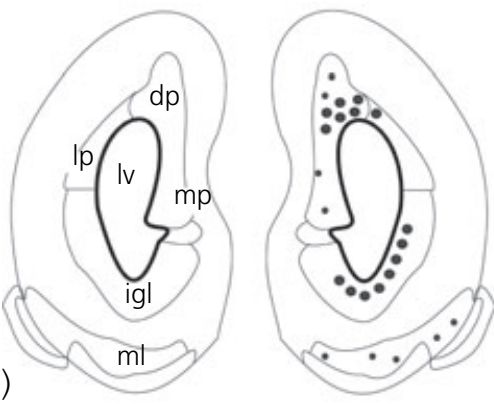

(C)
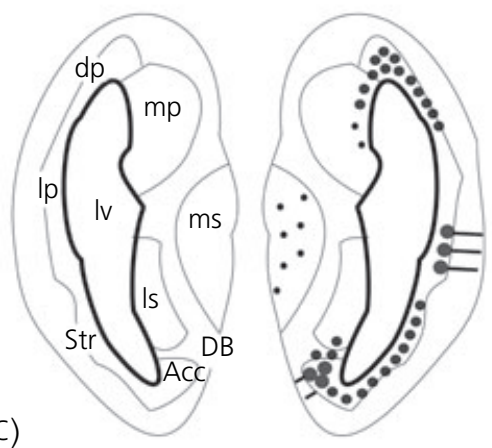

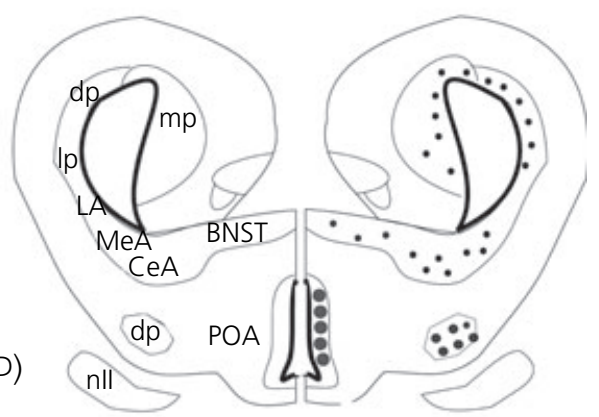

(E)

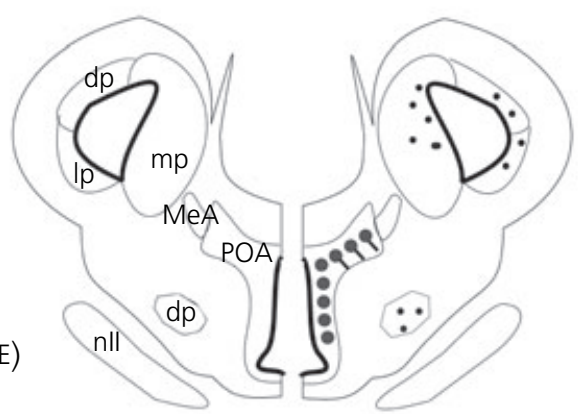

( $\mathrm{F})$

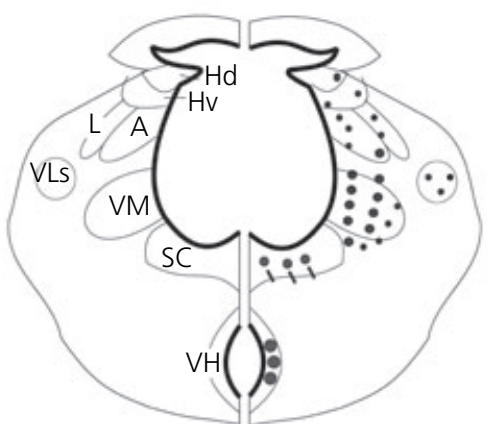

FIG. 2. Schematic coronal illustration of corticotrophin-releasing hormone (CRH)-immunoreactivity (ir) distribution in forebrain regions of juvenile Xenopus laevis. The drawing at the top of the figure shows a dorsal view of the whole brain. xCRH-ir in coronal sections (16 $\mu$ m) of juvenile $X$. laevis brain. Letters correspond to the rostro-caudal location of sections as depicted in the whole brain drawing. Large circles represent large, robust CRH-ir, small circles represent smaller cells with less reactive $\mathrm{CRH}$-ir, and lines represent $\mathrm{CRH}$-ir fibres. Robust $\mathrm{CRH}$-ir was observed in the lateral pallium (lp), striatum (Str), nucleus accumbens (Acc), anterior preoptic area (POA) and ventral hypothalamus (VH). See Table 1 for a complete description of abbreviations. The anatomical drawings are from Tuinhof et al. (86) with modification of basal ganglia subdivisions according to Marin et al. (64).

semicircularis (homologue of the mammalian inferior colliculi), and various tegmental nuclei (Fig. $3 \mathrm{H}, \mathrm{I}$; see also Fig. 5C,D).

\section{Rhombencephalon}

Robust CRH-ir was localized to the locus coeruleus (Fig. 3J; see also Fig. 5E) and the cerebellum (primarily the Purkinje cell layer, Fig. 3K; see also Fig. 5F). Smaller immunoreactive cells were localized to the reticular nuclei, and the nuclei of cranial nerves V (trigeminal motor), VIIId/v (nucleus of the lateral line), IX (glossopharyngeal) and $\mathrm{X}$ (vagal) (Fig. 3K-M; see also Fig. 5G).

\section{Rostral spinal cord}

$\mathrm{CRH}$-ir was restricted to the ventral horn of the rostral spinal cord. Robust staining was present in the large pyramidalshaped lateral motor neurones (Fig. $3 \mathrm{~N}$ ). Less intense CRH-ir was observed in smaller cells of the medial and dorsal regions of the ventral horn. Caudal regions of the spinal cord were not examined. 
TABLE 1. Abbreviations.

\begin{tabular}{|c|c|}
\hline Abbreviation & Definition \\
\hline A & Anterior thalamic nucleus \\
\hline Acc & Nucleus accumbens \\
\hline BNST & Bed nucleus of the stria terminalis \\
\hline $\mathrm{Cb}$ & Cerebellum \\
\hline DB & Nucleus of the diagonal band of Broca \\
\hline $\mathrm{dp}$ & Dorsal pallium \\
\hline Hd & Dorsal habenular nucleus \\
\hline $\mathrm{Hv}$ & Ventral habenular nucleus \\
\hline igl & Internal granule cell layer \\
\hline Ip & Interpeduncular nucleus \\
\hline Is & Nucleus isthmi \\
\hline gl & Glomerular layer \\
\hline La & Lateral thalamic nucleus, pars anterior \\
\hline LA & Lateral amygdala \\
\hline $\mathrm{LC}$ & Locus coeruleus \\
\hline $\operatorname{lmf}$ & Lateral motor field of spinal grey \\
\hline lp & Lateral pallium \\
\hline Lpv & Lateral thalamic nucleus, pars posteroventralis \\
\hline ls & Lateral septum \\
\hline lv & Lateral ventricle \\
\hline ME & Median eminence \\
\hline $\mathrm{MeA}$ & Medial amygdala \\
\hline $\mathrm{ml}$ & Mitral layer \\
\hline $\mathrm{mp}$ & Medial pallium \\
\hline $\mathrm{ms}$ & Medial septum \\
\hline $\mathrm{NPv}$ & Nucleus of the paraventricular organ \\
\hline nII & Cranial nerve II \\
\hline $\mathrm{nV}$ & Nervus trigeminus \\
\hline nIX & Nervus glossopharyngeus \\
\hline $\mathrm{nX}$ & Nervus vagus \\
\hline $\mathrm{P}$ & Posterior thalamic nucleus \\
\hline $\mathrm{Pd}$ & Pars distalis \\
\hline $\mathrm{Pi}$ & Pars intermedia \\
\hline Pn & Pars nervosa \\
\hline POA & Preoptic area \\
\hline $\mathrm{Ra}$ & Raphe nucleus \\
\hline $\mathrm{Rm}$ & Nucleus reticularis medius \\
\hline $\mathrm{SC}$ & Suprachiasmatic nucleus \\
\hline sol & Solitary nucleus \\
\hline Str & Striatum \\
\hline tect & Optic tectum \\
\hline tegm & Mesencephalic tegmentum \\
\hline $\mathrm{Tn}$ & Tegmental nuclei \\
\hline Tor & Torus semicircularis \\
\hline ТP & Posterior tuberculum \\
\hline $\mathrm{VH}$ & Ventral hypothalamic nucleus \\
\hline VLs & Superficial ventral nucleus \\
\hline VM & Ventromedial thalamic nucleus \\
\hline $\mathrm{Vm}$ & Nucleus motorius nervi trigemini \\
\hline Vpr & Nucleus sensorius principalis nervi trigemini \\
\hline $\mathrm{IXm}$ & Nucleus motorius nervi glossopharyngei \\
\hline $\mathrm{Xm}$ & Nucleus motorius nervi vagi \\
\hline
\end{tabular}

\section{Effects of shaking stressor on CRH-ir in the CNS}

Exposure of juvenile frogs to shaking stress resulted in the rapid activation of the hypothalamic-pituitary-interrenal (HPI) axis as demonstrated by a 3.6-fold increase in plasma corticosterone by $30 \mathrm{~min}$ and a 4.3 -fold increase by $3 \mathrm{~h}$ (Fig. 6); plasma corticosterone continued to increase by 20 -fold up to $6 \mathrm{~h}$.

We analysed an intermediate time point $(4 \mathrm{~h})$ for changes in $\mathrm{CRH}$-ir in the frog CNS. The shaking stressor produced a robust increase in the intensity of $\mathrm{CRH}$-ir staining and the number of CRH-ir positive neurones in the POA (Fig. 7). In stressed animals, greater intensity of $\mathrm{CRH}$ staining was observed in both the ependymal and subependymal zones compared to unstressed controls. Densitometric analysis revealed that shaking stress significantly increased $\mathrm{CRH}$-ir count density in the POA (ependymal and subependymal zones analysed together; $177 \%$ of control, $n=6 /$ treatment, $\mathrm{P}=0.0001$ ) (Fig. 7). Exposure to the shaking stressor also significantly increased CRH-ir in the MeA $(134 \%$ of control, $\mathrm{n}=5-6 /$ treatment, $\mathrm{P}=0.028)$ and in the BNST $(151 \%$ of control, $\mathrm{n}=5-6 /$ treatment, $\mathrm{P}=0.003$ ) at the level of POA (Fig. 7).

The shaking stressor did not alter $\mathrm{CRH}$-ir in the median eminence $(\mathrm{n}=5 /$ treatment, $\mathrm{P}=0.8238)$. No changes in CRH-ir were observed in the nucleus accumbens $(\mathrm{n}=5 /$ treatment, $\mathrm{P}=0.235)$, the locus ceoruleus $(\mathrm{LC})(\mathrm{n}=5-6 /$ treatment, $P=0.365)$, or the cerebellum $(n=5-6 /$ treatment, $\mathrm{P}=0.168)$.

\section{Effects of shaking stress on Fos-LI}

As previously described by Ubink et al. (33), we found FosLI to be exclusively nuclear with varying intensity from cell to cell. In the CNS of unstressed frogs, Fos-LI positive nuclei were occasionally observed in the internal granule cell layer, striatum, nucleus accumbens, lateral pallium and ventral hypothalamic nucleus. No Fos-LI positive neurones were seen in the POA in unstressed frogs, nor were they detected in other regions of the hypothalamus, amygdala, BNST, thalamus, pituitary, optic tectum, cerebellum or spinal cord. Following exposure to $4 \mathrm{~h}$ of shaking stressor, we observed an increase in Fos-LI positive cells throughout the brain. In addition to more Fos-LI-positive cells in the same regions as in the unstressed frog brains, detectable Fos-LI expanded to the lateral septum, medial pallium, lateral and medial amygdala, BNST, POA, various thalamic nuclei, suprachiasmatic nucleus, posterior tuberculum, optic tectum, torus semicircularis and tegmental nuclei. By contrast, we observed no Fos-LI-positive cells in the cerebellum or the LC following exposure to the shaking stressor. We quantified the robust increase in the number of Fos-LI positive cells in the POA, which were mainly localized to the rostro-ventral region $(\mathrm{n}=5-6 /$ treatment, $\mathrm{P}=0.002$; Fig. 8$)$. The total number of Fos-LI-positive cells in the POA differed significantly between individuals, ranging from 14 to 150 per animal.

Dual immunofluorescent, confocal microscopy for $\mathrm{CRH}$ and Fos in the POA showed that these two proteins were colocalized in a subset of Fos-LI-positive neurones (Fig. 9). However, not all CRH-positive cells exhibited Fos-LI. We were unable to quantify the numbers of Fos-LI, CRH-ir and CRH-ir + Fos-LI positive cells precisely in this experiment.

\section{Discussion}

We have mapped the distribution of CRH-positive somata and fibres in the brain and rostral spinal cord of $X$. laevis using a homologous and highly specific affinity-purified antiserum. For the first time, we also show stressor-induced changes in the physiology of discrete populations of $\mathrm{CRH}$ neurones in the CNS of a nonmammalian species. The 

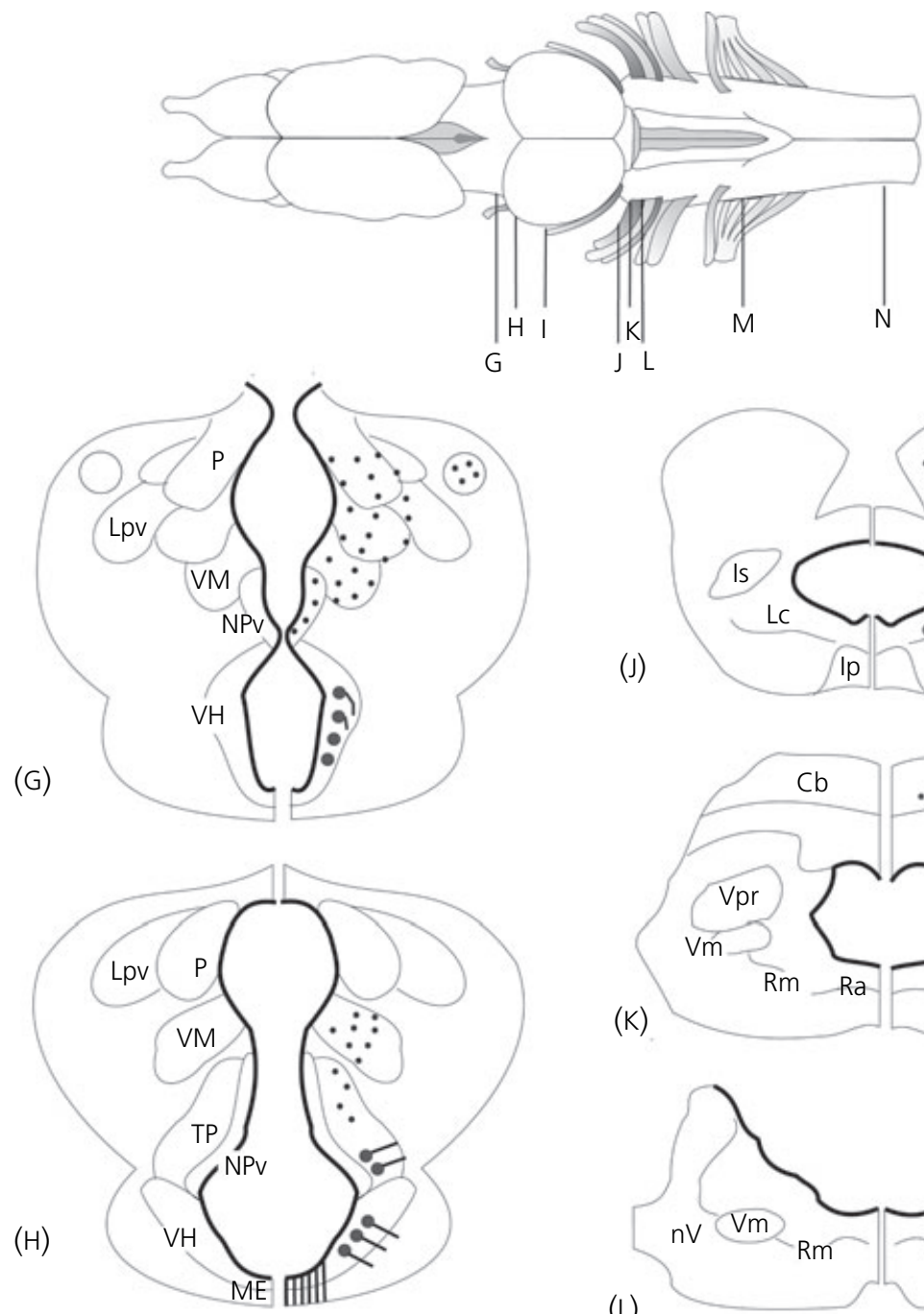

(J)
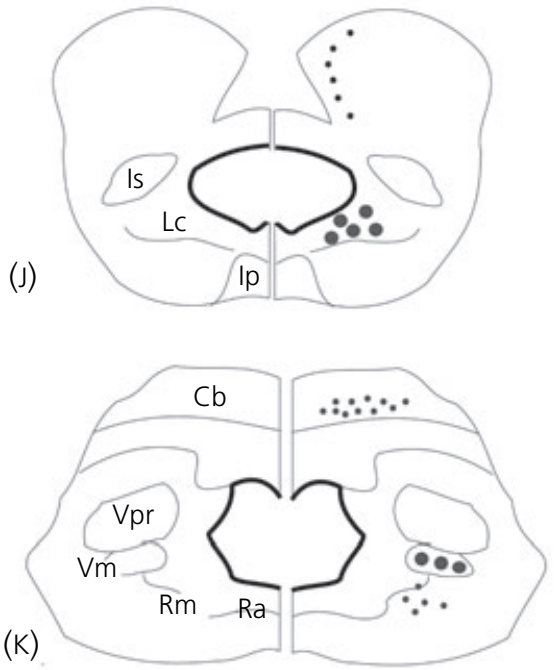

(L)
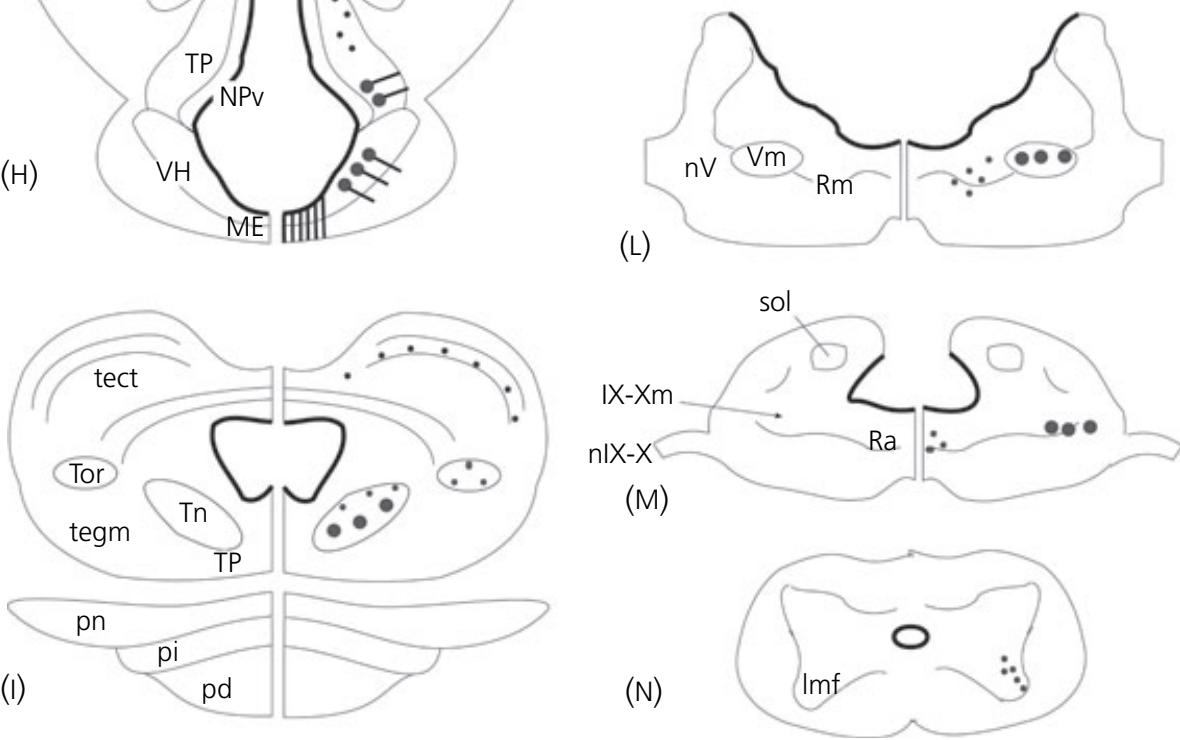

FIG. 3. Schematic coronal illustration of corticotrophin-releasing hormone (CRH)-immunoreactivity (ir) distribution in hindbrain and rostral spinal cord regions of juvenile Xenopus laevis. The drawing at the top of the figure shows a dorsal view of the whole brain. Letters correspond to the rostro-caudal location of sections as depicted in the whole brain drawing. Large circles represent large, robust CRH-ir, small circles represent smaller cells with less reactive xCRH-ir, and lines represent CRH-ir fibres. Robust CRH-ir was observed in the ventral thalamus (VH), posterior tuberacle (TP), median eminence (ME), cerebellum $(\mathrm{Cb})$, locus coeruleus (LC) and lateral motor neurones of the spinal cord, lmn. See Table 1 for a complete description of abbreviations.

distribution of CRH-ir within the hypothalamus of $X$. laevis reported here is in principal agreement with the distribution of CRH-ir described in other amphibian species in which antisera to mammalian CRHs were used $(9,11,14,15,30)$. Our findings of abundant CRH somata in the POA and $\mathrm{CRH}$-ir in the external zone of the ME and the existence of fibres projecting from the POA to the ME are consistent with previous studies and further support a role for CRH as a hypophysiotrophin in amphibians. The absence of CRH-ir cells in all pituitary lobes in our study is consistent with previous findings in other amphibian species [Rana tigrina (15); Rana castenbeiana $(11,14)]$ but contrary to previous 

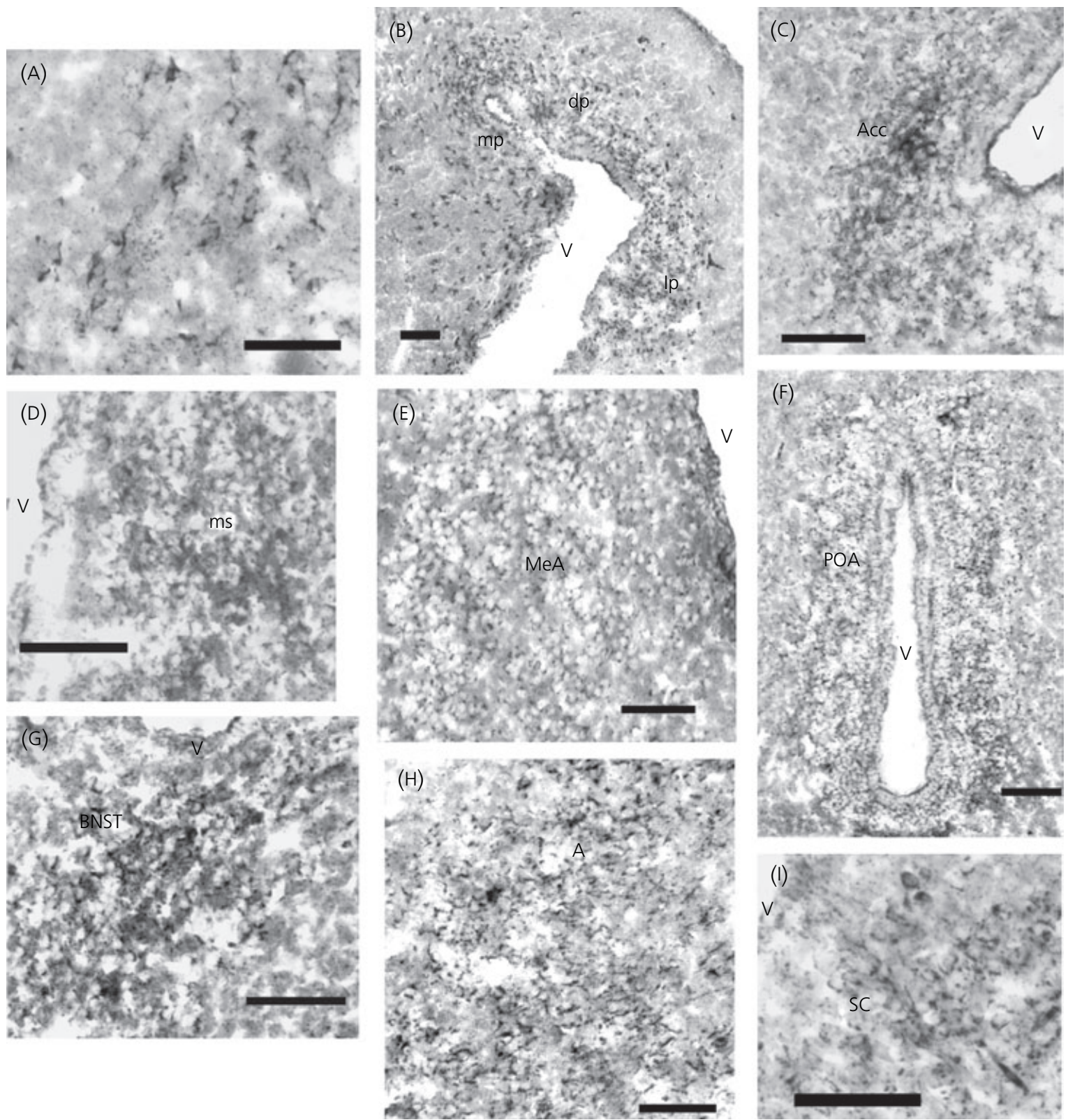

Fig. 4. Photomicrographs of transverse sections through the forebrain and part of the midbrain of juvenile Xenopus laevis showing the distribution of corticotrophin-releasing hormone (CRH)-immunoreactive (ir) somata and fibres. (A) Mitral layer of the olfactory bulb (ml). (B) Pallium. (C) Nucleus accumbens (Acc). (D) Medial septum (ms). (E) Medial amygdala (MeA). (F) Anterior preoptic area (POA). (G) Bed nucleus of the stria terminalis (BNST). (H) Anterior thalamic nucleus (A). (I) Suprachiasmatic nucleus (SC). See Table 1 for a complete description of abbreviations. Scale bars $=75 \mu \mathrm{m}$. V, ventricle.

reports in $X$. laevis in which heterologous antisera were used $(13,37)$. However, recent data suggest that the majority of $\mathrm{CRH}$-like immunoreactivity in the $X$. laevis pituitary neural lobe is derived from UCN1 (M. Calle, L. Wang, G. J. H. Corstens, T. Kozicz, R. J. Denver, H. P. Barendregt and E. W. Roubos, unpublished data).

Few studies have examined the CRH-ir in locations outside of the hypothalamic/pituitary region in amphibians in detail. Our data provide the first detailed distribution map of CRHir in the telecephalon, diencephalon, mesencephalon, rhombencephalon and rostral spinal cord in an amphibian species. The distribution of $\mathrm{CRH}$-ir in the telecephalon of $X$. laevis is consistent with previous results obtained in Rana tigrina and
Rana ridibunda $(13,15)$. We also identified CRH-ir positive cells and fibres in the amygdala, which is in agreement with previous reports in frogs $(11,15)$, reptiles $(38-40)$, birds $(41$, 42) and mammals (43). In the mesencephalon of other amphibian species, CRH-ir was reportedly restricted to the interpeduncular nucleus and tectal regions $(9,15)$. By contrast, in $X$. laevis, we observed expanded mesencephalic sites of $\mathrm{CRH}$-ir, including the oculomotor nuclei, tectal regions, the torus semicirculus (homologue of the mammalian inferior colliculi) and various tegmental nuclei. Consistent with our study, the oculomotor complex has been shown to express CRH-ir in reptiles $(38,40)$ and birds (44) while, in an amphibian, this structure was recently shown to express 

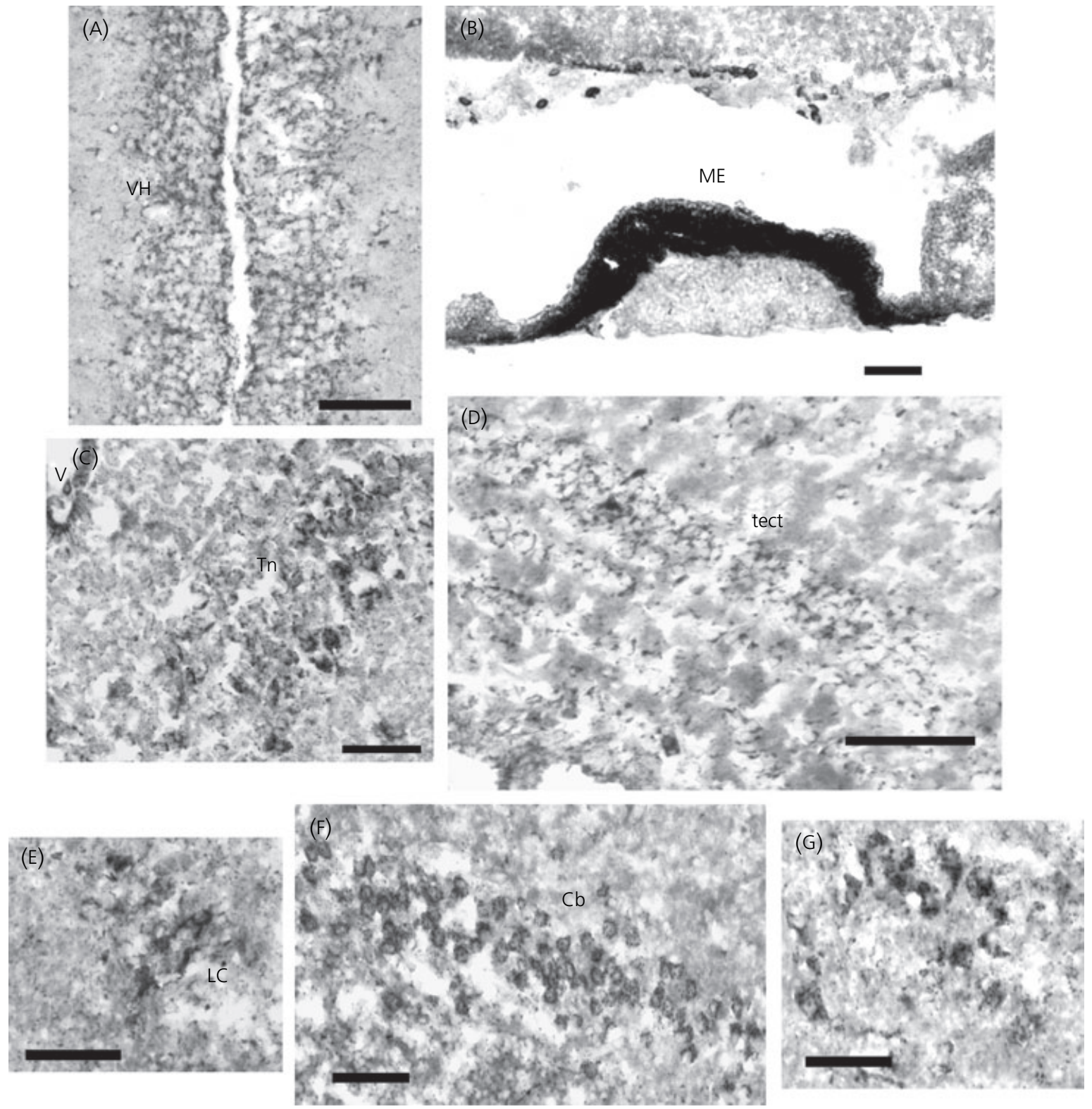

Fig. 5. Photomicrographs of transverse sections through part of the midbrain and the hindbrain of juvenile Xenopus laevis showing the distribution of corticotrophin-releasing hormone (CRH)-immunoreactive (ir) somata and fibres. (A) Ventral hypothalamic nucleus (VH). (B) Medium eminence (ME). (C) Tegmental nuclei (Tn). (D) Optic tectum (tect). (E) Locus coeruleus (LC). (F) Cerebellum (Cb). (G) Motor nucleus of the trigeminal nerve (Vm). See Table 1 for a complete description of abbreviations. Scale bars $=75 \mu \mathrm{m}$. V, ventricle.

UCN-like-ir [Rana esculenta (45); using a heterologous antiserum]. In the rhombencephalon, we identified robust $\mathrm{CRH}$-ir in the locus coeruleus and the cerebellum (primarily the Purkinje cell layer). Although this pattern of $\mathrm{CRH}$-ir has not been described in other amphibian species, CRH is widely expressed in the cerebellum (all three layers) and in the locus coeruleus in mammals $(41,46,47)$. In support of our findings in $X$. laevis, the torus semicirculus and tectal regions are also regions of CRH-ir in other vertebrates [reptiles (39); birds (41); mammals (48)]. Reticular locations and cranial nerves have not previously been shown to be CRH immunoreactive in amphibian species; however, a number of other vertebrate species including reptiles $(38,40)$ birds $(41,44,49)$ and mammals $(43,46,47)$ exhibit $\mathrm{CRH}$-ir in these areas. Ours is the first study to report CRH-ir in the spinal cord of amphibians. It should be noted that it is not clear whether previous studies in amphibians investigated rostral spinal cord levels for CRH-ir. Spinal cord CRH-ir has been described in mammals; but, unlike frogs, it was localized to the dorsal horn (48).

The wide distribution of CRH in the frog CNS is similar to that reported in mammals, and further supports a role for CRH as a neurotransmitter/neuromodulator in addition to its role as a neurohormone. The existence of CRH-ir in the subependymal zones of the telecephalon, in the amygdala, the cerebellum, locus coeruleus, various cranial nerve nuclei, and the spinal cord in both mammals $(43,47,50)$ and the frog, suggests that the pattern of central CRH expression and CRH neuronal 


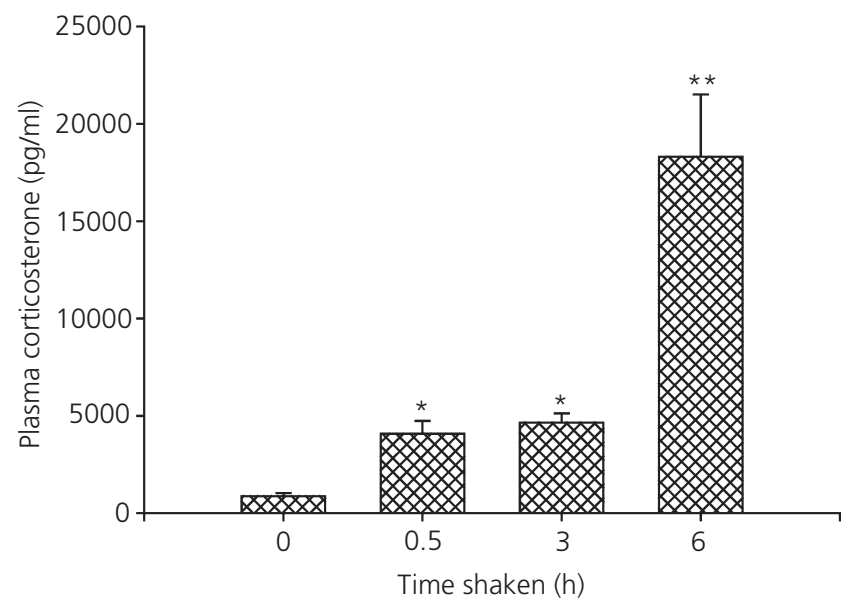

FIG. 6. Plasma corticosterone concentrations of Xenopus laevis juveniles exposed to shaking stress for various times $(n=10 /$ time point). Data presented are the mean \pm SEM. Significant differences from unstressed controls are denoted $(* \mathrm{P}<0.05$ and $* * \mathrm{P}<0.01)$.

circuitry arose early in vertebrate evolution; see also (2). Furthermore, our study describes for the first time the presence of descending CRH-ergic pathways in a nonamniote species. Lovejoy and Balment (2) suggested that amphibians could represent a transitional species with respect to descending $\mathrm{CRH}$-ergic pathways, and our results lend support to this idea.

It is now well established that the mammalian PVN (homologous to the amphibian POA) is the principal site of neuroendocrine responses to stress (51). Early studies in an amphibian (Bufo melanosticus) found an elevation in plasma corticosteroids after electrical stimulation of the POA, ventral hypothalamus, or the median eminence, but not after stimulation of other brain regions (52). Furthermore, lesioning of the ventral region of the POA in $X$. laevis tadpoles caused the pituitary corticotropes to regress (53). In the present study, we investigated the effects of a physical stressor, handling/shaking on $\mathrm{CRH}$ neuronal physiology in $X$. laevis. Exposure to the shaking stressor for $4 \mathrm{~h}$ caused a robust increase in both the $\mathrm{CRH}$-ir staining intensity and the number of cells stained in the POA compared to unstressed controls (Fig. 5). We also observed significant increases in CRH-ir in the MeA and BNST, which suggests that these structures are involved in mediating the stress response. By contrast, we found no changes in CRH-ir in the median eminence, nucleus accumbens, locus coeruleus or cerebellum. The robust increase in CRH-ir in the POA and the parallel elevation of plasma corticosterone supports the view that these are the primary hypophysiotropic CRH neurones regulating the activity of the HPI axis in $X$. laevis.

Our findings that CRH-ir was increased in the MeA and in the BNST at the level of POA in frogs represents the first report that $\mathrm{CRH}$ neurones resident in these CNS structures are responsive to stress. Studies of neuronal connections of the amygdala in mammals reveal extensive connections with cortical and subcortical regions; for a review, see $(54,55)$. Electrical stimulation of the amygdala of rats elicited autonomic, endocrine and behavioural responses similar to those induced by exposure to stressors (56-58). In mammals, the central nucleus of the amygdala (CeA) is involved with fear/ anxiety-related behaviours, and the MeA has been shown to play a role in cardiovascular responses to restraint stress and the control of haemodynamics $(56,57,59-61)$. The BNST is believed to play an important role in stress regulation of the HPA axis by relaying to the PVN from the amygdala and the hippocampus $(62,63)$.

The functions of the different compartments of the amygdala and the BNST in nonmammalian species are poorly understood. We followed the anatomical definition of these nuclei suggested by Marin et al. (64) for the frog. Among the compartments of the amygdaloid complex in $X$. laevis, the CeA was not easily identified in our analyses. Thus, the MeA region that we analysed could include a small portion of the dorsal CeA because there is no anatomical marker to clearly separate the two parts. Nonetheless, our results clearly show that the MeA and the BNST are involved in stress-circuitry in the amphibian CNS as in mammals, suggesting that their stress-related functions were established before the divergence of the amphibian and amniote lineages.

A critical component of the integrated physiological response to a variety of stressors is the locus coeruleusnoradrenaline (LC-NA)/autonomic nervous system located in the brainstem $(65,66)$. The LC-NA/autonomic system activates the mesocortical and mesolimbic dopaminergic system, as well as the amygdala/hippocampal complex during stress (59, 67-69). Furthermore, activation of the LC can increase hypothalamic CRH secretion (70-74). CRH has been proposed to function as a neurotransmitter to initiate autonomic and behavioural responses via activation of the LC-NA system during stress $(8,75)$. We identified CRH-ir in the hindbrain in $X$. laevis, but we did not observe changes in $\mathrm{CRH}$-ir in the LC or in the cerebellum following exposure to the shaking stressor. It is possible that we missed earlier or later changes in $\mathrm{CRH}$-ir in these regions because we examined only a single time point in the current study. It is also possible that other types of stressor not analysed in our study might preferentially activate hindbrain $\mathrm{CRH}$ neurones. For example, Boorse and Denver (76) found that exposure of Western spadefoot toad tadpoles to simulated pond drying increased hindbrain $\mathrm{CRH}$ content (as measured by tissue extraction and RIA). Further study is required to reveal the role that extrahypothalamic $\mathrm{CRH}$ neurones play in stress responses in amphibians.

The immediate early gene c-fos has been widely used as a maker of neuronal activation, especially of stress-response circuitry $(77,78)$. Studies in rodents show that c-fos mRNA and/or Fos-ir is increased in stress-related structures in the brain in response to a variety of stressors. For example, c-fos mRNA expression was increased in the MeA and lateral septum following exposure to two acute stressors (immobilization and electrical foot-shock), in the MeA, lateral septum and the suprachiasmatic nucleus following exposure to a novel stressor (open field), and was induced in the $\mathrm{CeA}$ and the lateral nucleus of the BNST by a systemic stressor (i.e. injection of cytokines) (78-81). Our observation that Fos-LI appeared in the MeA, BNST, lateral septum and suprachiasmatic nucleus following exposure to $4 \mathrm{~h}$ of shaking stressor is in agreement with these data, suggesting that much of the stress circuitry is conserved among tetrapods. One structure 

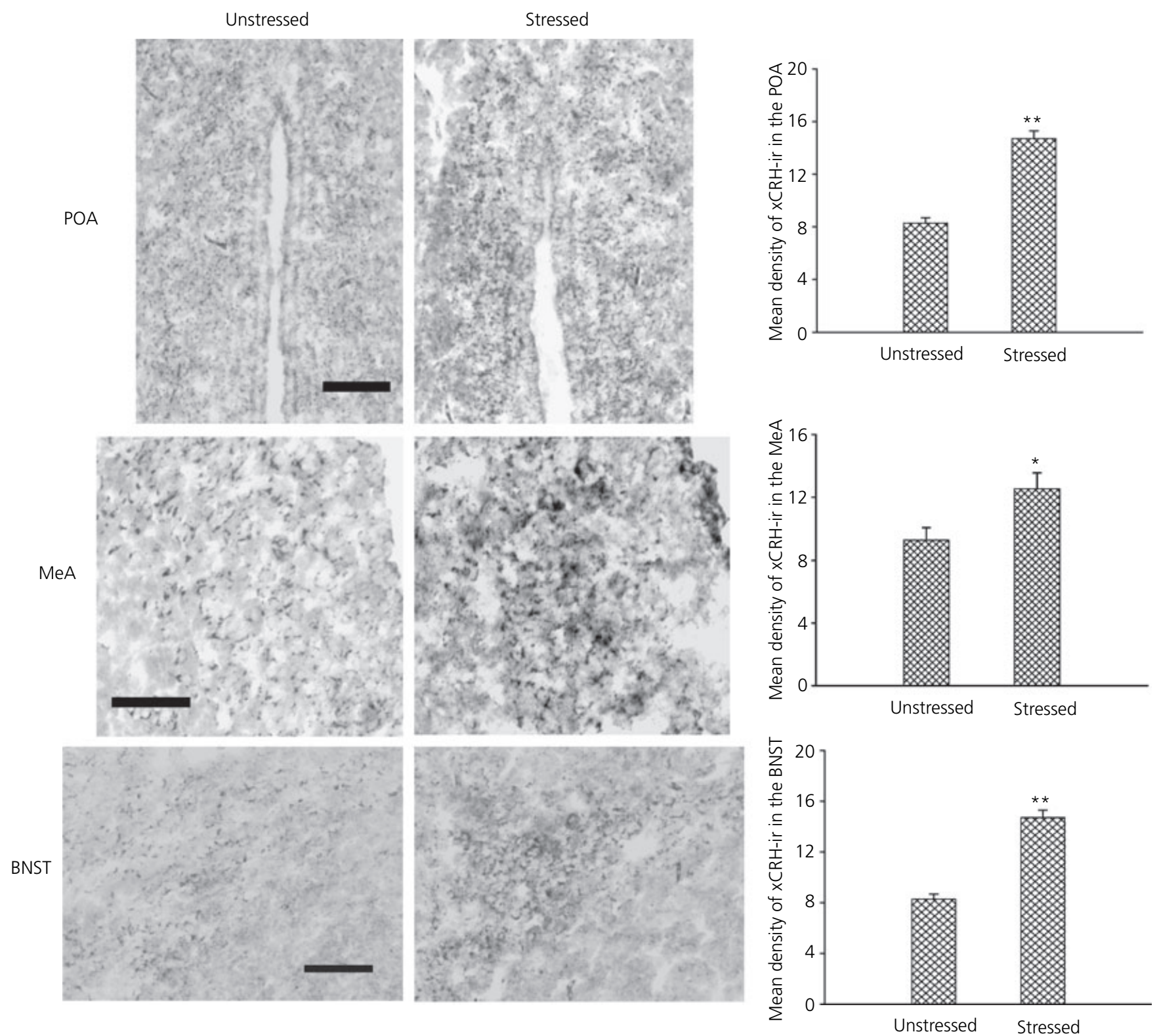

Fig. 7. Effects of shaking stress on corticotrophin-releasing hormone (CRH)-immunoreactivity (ir) in the anterior preoptic area (POA), medial amygdala $(\mathrm{MeA})$ and bed nucleus of the stria terminalis (BNST) of juvenile Xenopus laevis. Micrographs are of representative transverse sections (12 $\mu \mathrm{m})$ in the same anatomical plane of the POA. Representative sections of unstressed animal brain are shown on the left, and those of stressed brain are shown on the right. Scale bar $=150 \mu \mathrm{m}$ in the micrographs of the POA, and $75 \mu \mathrm{m}$ in the micrographs of the MeA and BNST. The graphs show densitometric analyses of CRH-ir in the POA, MeA and BNST of juvenile $X$. laevis following exposure to $4 \mathrm{~h}$ of shaking stress. CRH-ir mean density was significantly increased in the POA, $\mathrm{MeA}$ and BNST in stressed $X$. laevis compared to unstressed controls. Data presented are the mean \pm SEM. Significant differences from unstressed control are denoted $(* \mathrm{P}<0.05$ and $* * \mathrm{P}<0.01)$.

that is invariably activated by stress in rodents is the PVN. In accordance with these data, our results show that the number of Fos-LI-positive cells is elevated in the POA in the frog $X$. laevis following exposure to shaking stress.

The robust increase in Fos-LI and its colocalization with CRH-ir in the frog POA, similar to that observed in the mammalian PVN $(82,83)$, suggests that the induction of Fos and $\mathrm{CRH}$ by stress are functionally linked. For example, both mammalian and frog CRH genes possess AP-1 sites to which Fos-Jun heterodimers can bind (84), and there is evidence that Fos can regulate CRH gene expression in rodents $(27,83,85)$.
In conclusion, our findings in the frog $X$. laevis show that the basic pattern of CRH expression in the CNS arose early in vertebrate evolution. Our data also lend further support to earlier studies suggesting that amphibians may be a transitional species for descending $\mathrm{CRH}$-ergic pathways. We found that $\mathrm{CRH}$ neurones in the frog brain exhibit changes in response to physical stress that parallel those seen in mammals, and thus are likely to play important roles in the mediation of neuroendocrine, behavioural and autonomic responses to stress. Stressor activation of the POA, MeA and BNST in the frog suggests that the stress-related functions of 
Unstressed

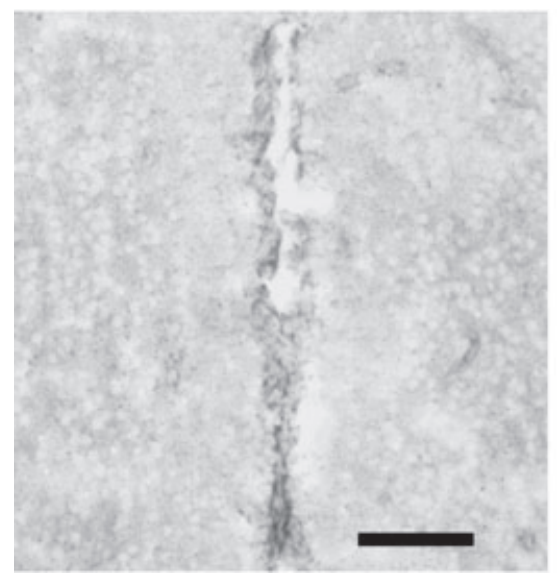

Stressed

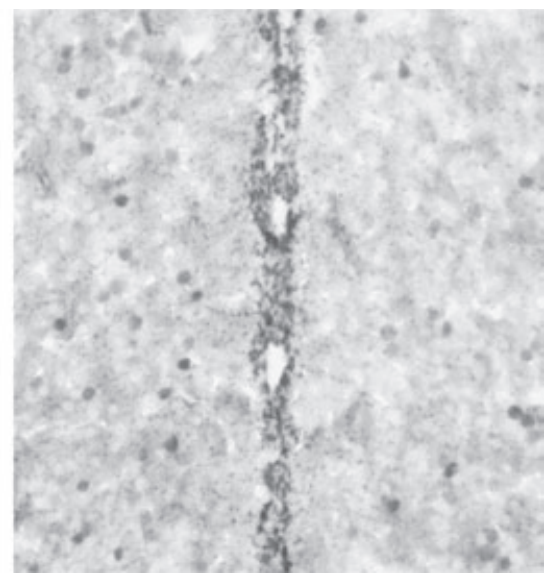

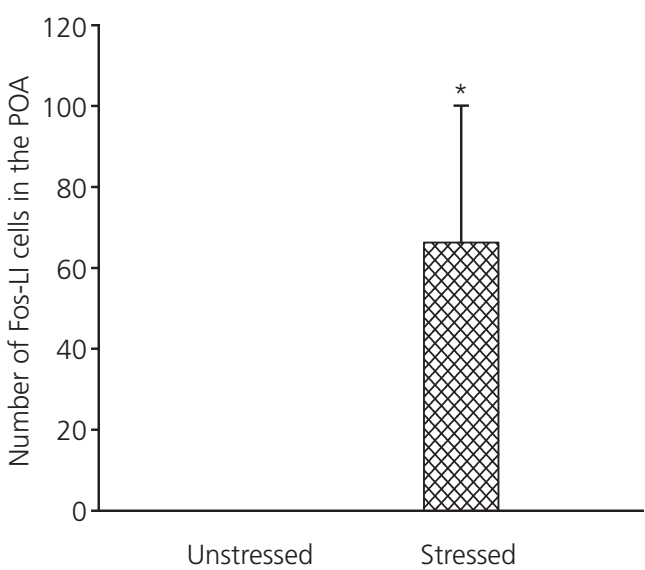

FIG. 8. Changes in Fos-like immunoreactivity (Fos-LI) in the anterior preoptic area (POA) in control (A) and shaking-stressed (B) juvenile Xenopus laevis. Scale bar $=75 \mu \mathrm{m}$. The graph shows that the total number of Fos-LI positive cells was significantly increased in the POA in stressed $X$. laevis compared to unstressed controls. Data presented are the mean \pm SEM. A significant difference from unstressed controls is denoted $(* \mathrm{P}<0.01)$.
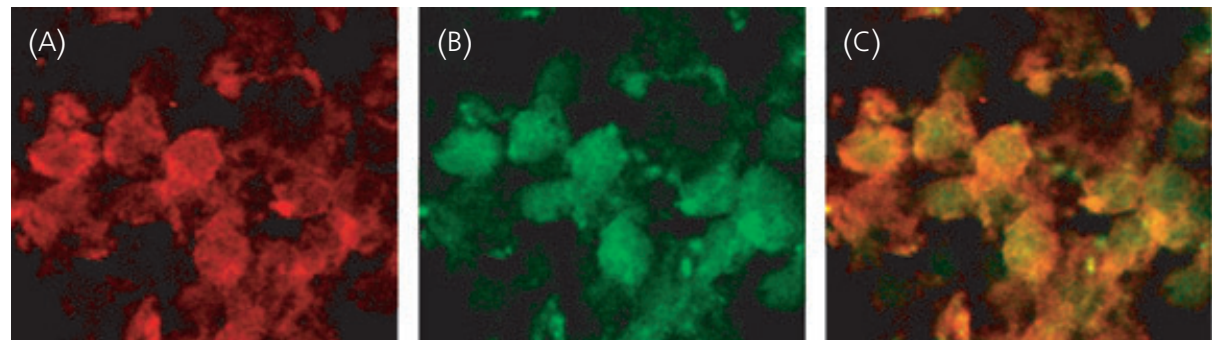

FIG. 9. Colocalization of corticotrophin-releasing hormone (CRH)-immunoreactivity (ir) and Fos-like immunoreactivity (Fos-LI) in the anterior preoptic area (POA). Immunofluorescence confocal microscopy was conducted on double-labelled transverse sections through the POA of frogs exposed to $4 \mathrm{~h}$ of shaking stressor. The same field of the POA was scanned to reveal CRH-ir (A, red) and Fos-LI (B, green). CRH-ir was mostly located in the cytoplasm of the cells, while Fos-LI was restricted to the nuclei. The merged image of CRH-ir and Fos-LI (C) shows colocalization of CRH-ir and Fos-LI in a subset of neurones in the POA. The ability to clearly distinguish cytoplasmic from nuclear staining is limited by the small size of the cells.

these CNS structures were established before the divergence of the amphibian and amniote lineages.

\section{Acknowledgements}

This research was supported by NSF grants IBN9974672 and IBN0235401 to R.J.D. We are grateful to Wylie Vale and Jean Rivier for supplying the synthetic $X$. laevis $\mathrm{CRH}$. We also thank Karen Glennemeier and Graham Boorse for help with the corticosterone RIA and the xCRH RIA, respectively.

\section{Accepted 30 September 2004}

\section{References}

1 Spiess J, Rivier J, Rivier C, Vale W. Primary structure of corticotropin-releasing factor from ovine hypothalamus. Proc Natl Acad Sci USA 1981; 78: 6517-6521.

2 Lovejoy DA, Balment RJ. Evolution and physiology of the corticotropin-releasing factor (CRF) family of neuropeptides in vertebrates. Gen Comp Endocrinol 1999; 115: 1-22.

3 Dautzenberg FM, Hauger RL. The CRF peptide family and their receptors: yet more partners discovered. Trends Pharmacol Sci 2002; 23: $71-77$.

4 Stenzel-Poore MP, Heldwein KA, Stenzel P, Lee S, Vale WW. Characterization of the genomic corticotropin-releasing factor
(CRF) gene from Xenopus laevis - 2 members of the CRF family exist in amphibians. Mol Endocrinol 1992; 6: 1716-1724.

5 Vale W, Spiess J, Rivier C, Rivier J. Characterization of a 41-residue ovine hypothalamic peptide that stimulates secretion of corticotropin and beta-endorphin. Science 1981; 213: 1394-1397.

6 Thompson RC, Seasholtz AF, Herbert E. Rat corticotropin-releasing hormone gene - sequence and tissue-specific expression. Mol Endocrinol 1987; 1: 363-370.

7 Sawchenko PE, Swanson LW. Organization of CRF immunoreactive cells and fibers in the rat brain: immunohistochemical studies. In: DeSouza, E, Nemeroff, C, eds. Corticotropin-Releasing Factor: Basic and Clinical Studies of a Neuropeptide. Boca Raton, FL: CRC, 1989.

8 Owens MJ, Nemeroff CB. Physiology and pharmacology of corticotropin-releasing factor. Pharmacol Rev 1991; 43: 425-473.

9 Olivereau M, Vandesande F, Boucique E, Ollevier F, Olivereau JM. Immunocytochemical localization and spatial relation to the adenohypophysis of a somatostatin-like and a corticotropin-releasing factor-like peptide in the brain of 4 amphibian species. Cell Tissue Res 1987; 247: 317-324.

10 Fasolo A, Andreone C, Vandesande F. Immunohistochemical localization of corticotropin-releasing factor (CRF)-like immunoreactivity in the hypothalamus of the newt, Triturus cristatus. Neurosci Lett 1984; 49: 135-142.

11 Gonzalez GC, Lederis K. Sauvagine-like and corticotropin-releasing factor-like immunoreactivity in the brain of the bullfrog (Rana catesbeiana). Cell Tissue Res 1988; 253: 29-37. 
12 Ogawa K, Suzuki E, Taniguchi K. Immunohistochemical studies on the development of the hypothalamohypophyseal system in Xenopus laevis. Anat Rec 1995; 241: 244-254.

13 Tonon MC, Burlet A, Lauber M, Cuet P, Jégou S, Gouteux L, Ling N, Vaudry H. Immunohistochemical localization and radioimmunoassay of corticotropin-releasing factor in the forebrain and hypophysis of the frog Rana ridibunda. Neuroendocrinology 1985; 40: 109-119.

14 Carr JA, Norris DO. Immunohistochemicallocalization of corticotropin-releasing factor-like and arginine vasotocin-like immunoreactivities in the brain and pituitary of the American bullfrog (Rana catesbeiana) during development and metamorphosis. Gen Comp Endocrinol 1990; 78: 180-188.

15 Bhargava S, Rao PDP. Distribution of corticotropin-releasing factor Immunoreactive neurons in the brain of the tigerfrog, Rana tigrina. Neurosci Lett 1993; 154: 27-30.

16 Herman JP, Schafer MKH, Sladek CD, Day R, Young EA, Akil H, Watson SJ. Chronic electroconvulsive shock treatment elicits upregulation of CRF and AVP messenger RNA in select populations of neuroendocrine neurons. Brain Res 1989; 501: 235-246.

17 Bartanusz V, Jezova D, Bertini LT, Tilders FJH, Aubry JM, Kiss JZ. Stress-induced increase in vasopressin and corticotropin-releasing factor expression in hypophysiotrophic paraventricular neurons. Endocrinology 1993; 132: 895-902.

$18 \mathrm{Ma}$ XM, Levy A, Lightman SL. Emergence of an isolated arginine vasopressin (AVP) response to stress after repeated restraint. A study of both AVP and corticotropin-releasing hormone messenger ribonucleic acid (RNA) and heteronuclear RNA. Endocrinology 1997; 138: 4351-4357.

19 Imaki T, Nahan JL, Rivier C, Sawchenko PE, Vale W. Differential regulation of corticotropin-releasing factor messenger RNA in rat brain regions by glucocorticoids and stress. J Neurosci 1991; 11: 585599.

20 Imaki T, Wang X-Q, Shibasaki T, Harada S, Chikada N, Takahashi C, Naruse M, Demura H. Chlordiazepoxide attenuates stress-induced activation of neurons, corticotropin-releasing factor (CRF) gene transcription and CRF biosynthesis in the paraventricular nucleus (PVN). Mol Brain Res 1995; 32: 261-270.

21 Kovacs KJ, Sawchenko PE. Regulation of stress-induced transcriptional changes in the hypothalamic neurosecretory neurons. J Mol Neurosci 1996; 7: 125-133.

22 Imaki T, Naruse M, Harada S, Chikada N, Imaki J, Onodera H, Demura H, Vale W. Corticotropin-releasing factor up-regulates its own receptor mRNA in the paraventricular nucleus of the hypothalamus. Mol Brain Res 1996; 38: 166-170.

23 Hsu DT, Chen FL, Takahashi LK, Kalin NH. Rapid stress-induced elevations in corticotropin-releasing hormone mRNA in rat central amygdala nucleus and hypothalamic paraventricular nucleus: An in situ hybridization analysis. Brain Res 1998; 788: 305-310.

24 Liu Y, Curtis JT, Fowler CD, Spencer C, Houpt T, Wang ZX. Differential expression of vasopressin, oxytocin and corticotrophinreleasing hormone messenger RNA in the paraventricular nucleus of the prairie vole brain following stress. $J$ Neuroendocrinol 2001; 13: 1059-1065.

25 Hand GA, Hewitt CB, Fulk LJ, Stock HS, Carson JA, Davis JM, Wilson MA. Differential release of corticotropin-releasing hormone $(\mathrm{CRH})$ in the amygdala during different types of stressors. Brain Res 2002; 949: 122-130.

26 Bruijnzeel AW, Stam R, Compaan JC, Wiegant VM. Stress-induced sensitization of $\mathrm{CRH}$-ir but not P-CREB-ir responsivity in the rat central nervous system. Brain Res 2001; 908: 187-196.

27 Kay-Nishiyama C, Watts AG. Dehydration modifies somal CRH immunoreactivity in the rat hypothalamus. an immunocytochemical study in the absence of colchicine. Brain Res 1999; 822: 251-255.

28 Imaki T, Katsumata H, Miyata M, Naruse M, Imaki J, Minami S. Expression of corticotropin-releasing hormone type 1 receptor in paraventricular nucleus after acute stress. Neuroendocrinology 2001; 73: $293-301$

29 Makino S, Shibasaki T, Yamauchi N, Nishioka T, Mimoto T, Wakabayashi I, Gold PW, Hashimoto K. Psychological stress increased corticotropin-releasing hormone mRNA and content in the central nucleus of the amygdala but not in the hypothalamic paraventricular nucleus in the rat. Brain Res 1999; 850: 136143 .
30 Verhaert P, Marivoet S, Vandesande F, DeLoof A. Localization of CRF immunoreactivity in the central nervous system of 3 vertebrate and one insect species. Cell Tissue Res 1984; 238: 49-53.

31 Denver RJ. Environmental stress as a developmental cue: Corticotropin-releasing hormone is a proximate mediator of adaptive phenotypic plasticity in amphibian metamorphosis. Horm Behav 1997; 31: 169-179.

32 Boorse GC, Denver RJ. Expression and hypophysiotropic actions of corticotropin-releasing factor in Xenopus laevis. Gen Comp Endocrinol 2004; 137: 272-282.

33 Ubink R, Jenks BG, Roubos EW. Physiologically induced Fos expression in the hypothalamo-hypophyseal system of Xenopus laevis. Neuroendocrinology 1997; 65: 413-422.

34 Negoescu A, Labat-Moleur F, Lorimier P, Lamarcq L, Guillermet C, Chambaz E, Brambilla E. F(ab) secondary antibodies: a general method for double immunolabeling with primary antisera from the same species - efficiency control by chemiluminescence. $J$ Histochem Cytochem 1994; 42: 433-437.

35 Glennemeier KA, Denver RJ. Developmental changes in interrenal responsiveness in anuran amphibians. Integr Comp Biol 2002; 42: 565-573.

36 Licht P, McCreery BR, Barnes R, Pang R. Seasonal and stress related changes in plasma gonadotropins, sex steroids, and corticosterone in the bullfrog, Rana catesbeiana. Gen Comp Endocrinol 1983; 50: 124-145.

37 Verburg-van Kemenade BML, Jenks BG, Cruijsen PMJM, Dings A, Tonon M-C, Vaudry H. Regulation of MSH release from the neurointermediate lobe of Xenopus laevis by CRF-like peptides. Peptides 1987; 8: 1093-1100.

38 Silveira PF, Breno MC, Puorto G, del Rio MPM, Mancera JM. Corticotropin-releasing hormone-like immunoreactivity in the brain of the snake Bothrops jararaca. Histochem $J$ 2001; 33: 685694.

39 Avalos MDL, Mancera JM, Perezfigares JM, Fernandezllebrez P. Immunocytochemical localization of corticotropin-releasing factor in the brain of the turtle, Mauremys caspica. Anat Embryol 1993; 188: $163-171$.

40 Mancera JM, Avalos MDL, Perezfigares JM, Fernandezllebrez P. The distribution of corticotropin-releasing factor-immunoreactive neurons and nerve fibers in the brain of the snake, Natrix mauracoexistence with arginine vasotocin and mesotocin. Cell Tissue Res 1991; 264: 539-548.

41 Richard S, Martinez-Garcia F, Lanuza E, Davies DC. Distribution of corticotropin-releasing factor-immunoreactive neurons in the central nervous system of the domestic chicken and Japanese quail. J Comp Neurol 2004; 469: 559-580.

42 Yamada S, Mikami S. Immunohistochemical localization of corticotropin-releasing factor (CRF)-containing neurons in the hypothalamus of the Japanese quail, Coturnix coturnix. Cell Tissue Res 1985; 239: 299-304.

43 Merchenthaler I, Vigh S, Petrusz P, Schally AV. Immunocytochemical localization of corticotropin-releasing factor (CRF) in the rat brain. Am J Anat 1982; 165: 385-396.

44 Bons N, Bouille C, Tonon MC, Guillaume V. Topographical distribution of CRF immunoreactivity in the pigeon brain. Peptides 1988; 9: 697-707.

45 Kozicz T, Arimura A, Maderdrut JL, Lazar G. Distribution of urocortin-like immunoreactivity in the central nervous system of the frog Rana esculenta. J Comp Neurol 2002; 453: 185-198.

46 Morin SM, Ling N, Liu XJ, Kahl SD, Gehlert DR. Differential distribution of urocortin- and corticotropin-releasing factor-like immunoreactivities in the rat brain. Neuroscience 1999; 92: 281291.

47 Swanson LW, Sawchenko PE, Rivier J, Vale WW. Organization of ovine corticotropin-releasing factor immunoreactive cells and fibers in the rat brain - an immunohistochemical study. Neuroendocrinology 1983; 36: 165-186.

48 Merchenthaler I. Corticotropin releasing-factor (CRF)-like immunoreactivity in the rat central nervous system - extrahypothalamic distribution. Peptides 1984; 5: 53-69.

49 Jozsa R, Vigh S, Schally AV, Mess B. Localization of corticotropinreleasing factor-containing neurons in the brain of the domestic fowl - an immunohistochemical study. Cell Tissue Res 1984; 236: 245248 . 
50 Shioda S, Nakai Y, Kitazawa S, Sunayama H. Immunocytochemical observations of corticotropin-releasing factor-containing neurons in the rat hypothalamus with special reference to neuronal communication. Acta Anat 1985; 124: 58-64.

51 Ziegler DR, Herman JP. Neurocircuitry of stress integration: anatomical pathways regulating the hypothalamo-pituitary-adrenocortical axis of the rat. Integr Comp Biol 2002; 42: 541-551.

52 Roy BB. Brain mechanisms responsible for ACTH release in the toad B. Melanostictus with a note on C. versicolor. Bull Univ Coll Med Calcutta 1969/71; 7/8: 1-13.

53 Notenboom CD, Terlou M, Maten ML. Evidence for corticotropin releasing factor (CRF) synthesis in preoptic nucleus of Xenopus laevis tadpoles - preliminary report based on lesion experiments. Cell Tissue Res 1976; 169: 23-31.

54 Sah P, Faber ESL, De Armentia ML, Power J. The amygdaloid complex: anatomy and physiology. Physiol Rev 2003; 83: 803-834.

55 McDonald AJ. Cortical pathways to the mammalian amygdala. Prog Neurobiol 1998; 55: 257-332.

56 Rosen JB, Davis M. Enhancement of acoustic startle by electricalstimulation of the amygdala. Behav Neurosci 1988; 102: 195.

57 Rosen JB, Davis M. Enhancement of electrically elicited startle by amygdaloid stimulation. Physiol Behav 1990; 48: 343-349.

58 Gelsema AJ, Agarwal SK, Calaresu FR. Cardiovascular responses and changes in neural activity in the rostral ventrolateral medulla elicited by electrical stimulation of the amygdala of the rat. $J$ Autonomic Nervous System 1989; 27: 91-100.

59 Gray TS. Amygdala: Role in autonomic and neuroendocrine responses to stress. In: McCubbin, JA, Kaufman, PG, Nemeroff, CB, eds. Stress, Neuropeptides and Systemic Disease. New York, NY: Academic Press, 1991: 37-53.

60 Kubo T, Okatani H, Nishigori Y, Hagiwara Y, Fukumori R, Goshima Y. Involvement of the medial amygdaloid nucleus in restraint stressinduced pressor responses in rats. Neurosci Lett 2004; 354: 84-86.

61 Cullinan WE, Herman JP, Battaglia DF, Akil H, Watson SJ. Pattern and time-course of immediate-early gene expression in rat brain following acute stress. Neuroscience 1995; 64: 477-505.

62 Herman JP, Cullinan WE. Neurocircuitry of stress: Central control of the hypothalamo-pituitary-adrenocortical axis. Trends Neurosci 1997; 20: 78-84.

63 Schulkin J, Gold PW, McEwen BS. Induction of corticotropinreleasing hormone gene expression by glucocorticoids: implication for understanding the states of fear and anxiety and allostatic load. Psychoneuroendocrinology 1998; 23: 219-243.

64 Marin O, Smeets WJAJ, Gonzalez A. Basal ganglia organization in amphibians: chemoarchitecture. J Compneurol 1998; 392: 285-312.

65 Mason JW. A review of psychoendocrine research on sympatheticadrenal medullary system. Psychosomatic Med 1968; 30: 631-\&.

66 McCarty R. Stress, behavior and the sympathetic-adrenal medullary system. In: Pohorecky, LA, Brick, J, eds. Stress and Alcohol Use. New York, NY: Elsevier Science Publishers, 1983: 7.

67 Deutch AY, Goldstein M, Roth RH. Activation of the locus coeruleus induced by selective stimulation of the ventral tegmental area. Brain Res 1986; 363: 307-314.

68 Roth RH, Tam SY, Ida Y, Yang JX, Deutch AY. Stress and the mesocorticolimbic dopamine systems. Ann NY Acad Sci 1988; 537: 138-147.

69 Deutch AY, Clark WA, Roth RH. Prefrontal cortical dopamine depletion enhances the responsiveness of mesolimbic dopamine neurons to stress. Brain Res 1990; 521: 311-315.

70 Calogero AE, Gallucci WT, Gold PW, Chrousos GP. Multiple feedback regulatory loops upon rat hypothalamic corticotropin- releasing hormone secretion - potential clinical implications. $J$ Clin Invest 1988; 82: 767-774.

71 Day TA, Ferguson AV, Renaud LP. Noradrenergic afferents facilitate the activity of tuberoinfundibular neurons of the hypothalamic paraventricular nucleus. Neuroendocrinology 1985; 41: 17-22.

72 Kannan H, Kasai M, Osaka T, Yamashita H. Neurons in the paraventricular nucleus projecting to the median eminence - a study of their afferent connections from peripheral baroreceptors, and from the A1-catecholaminergic area in the ventrolateral medulla. Brain Res 1987; 409: 358-363.

73 Tanaka J, Kaba H, Saito H, Seto K. Inputs from the A1 noradrenergic region to hypothalamic paraventricular neurons in the rat. Brain Res 1985; 335: 368-371.

74 Plotsky PM. Facilitation of immunoreactive corticotropin-releasing factor secretion into the hypophyseal-portal circulation after activation of catecholaminergic pathways or central norepinephrine injection. Endocrinology 1987; 121: 924-930.

75 Dunn AJ, Berridge CW. Physiological and behavioral responses to corticotropin-releasing factor administration - is CRF a mediator of anxiety or stress responses? Brain Res Rev 1990; 15: 71-100.

76 Boorse GC, Denver RJ. Endocrine mechanisms underlying plasticity in metamorphic timing in spadefoot toads. Integr Comp Biol 2003; 43: 646-657.

77 Ceccatelli S, Villar MJ, Goldstein M, Hokfelt T. Expression of c-Fos immunoreactivity in transmitter-characterized neurons after stress. Proc Natl Acad Sci USA 1989; 86: 9569-9573.

78 Emmert MH, Herman JP. Differential forebrain c-fos mRNA induction by ether inhalation and novelty: evidence for distinctive stress pathways. Brain Res 1999; 845: 60-67.

79 Day HEW, Akil H. Differential pattern of $c$-fos mRNA rat brain following central and systemic administration of interleukin-1-beta: implications for mechanism of action. Neuroendocrinology 1996; 63: 207-218.

80 Sawchenko PE, Brown ER, Chan RKW, Ericsson A, Li HY, Roland BL, Kovacs KJ. The paraventricular nucleus of the hypothalamus and the functional neuroanatomy of visceromotor responses to stress. Prog Brain Res 1996; 107: 201-222.

81 Imaki T, Shibasaki T, Hotta M, Demura H. Intracerebroventricular administration of corticotropin-releasing factor induces $c$-fos mRNA expression in brain regions related to stress responses - comparison with pattern of c-fos mRNA induction after stress. Brain Res 1993; 616: $114-125$.

82 Imaki T, Shibasaki T, Hotta M, Demura H. Early Induction of $c$-fos precedes increased expression of corticotropin-releasing factor messenger ribonucleic acid in the paraventricular nucleus after immobilization stress. Endocrinology 1992; 131: 240-246.

83 Watts AG, Sanchez-Watts G. Interactions between heterotypic stressors and corticosterone reveal integrative mechanisms for controlling corticotropin-releasing hormone gene expression in the rat paraventricular nucleus. J Neurosci 2002; 22: 6282-6289.

84 Yao M, Westphal N, Denver RJ. Acute stress-induced elevation in corticotropin-releasing hormone expression in Xenopus laevis. Integr Comp Biol 2002; 42: 1341-1341.

85 Timofeeva E, Huang QL, Richard D. Effects of treadmill running on brain activation and the corticotropin-releasing hormone system. Neuroendocrinology 2003; 77: 388-405.

86 Tuinhof R, Ubink R, Tanaka S, Atzori C, van Strien FJC, Roubos EW. Distribution of pro-opiomelanocortin and its peptide end products in the brain and hypophysis of the aquatic toad, Xenopus laevis. Cell Tissue Res 1998; 292: 251-265. 